\title{
KAIDAH PRINSIP-PRINSIP DAKWAH \\ (Tinjauan Fikih Dakwah)
}

\author{
Kamaluddin \\ Fakultas Dakwah dan Ilmu Komunikasi Institut Agama Islam Negeri Padangsidimpuan \\ Jalan T. Rizal Nurdin KM. 4,5 Sihitang Padangsidimpuan \\ E-mail: kamaluddin@yahoo.co.id
}

\begin{abstract}
Abstrak
Pelaksanaan dakwah memiliki beberapa kaidah yang menjadi prinsip-prinsip dasar yang harus diterapkan oleh para da'i, baik menyangkut pesan, metode, mad'u dan lingkungan dakwah. Kaidah prinsip-prinsip tersebut sangat humanis. Kaidah tersebut antara lain terciptanya keharmonisan antara kelembutan dan ketegasan, amar ma'ruf nahi mungkar sesuai kemampuan yang dimiliki, agar tidak menimbulkan kerusakan yang lebih besar. Demikian juga dalam aspek budaya, perlunya prinsip dakwah multikultural yang dapat mengambil hal-hal lama yang baik dari kerifan lokal serta menolak hal-hal baru yang tidak sesuai dengan Islam. Tidak ada pemaksaan dalam berdakwah, da'i hanya dituntut proses sesuai kaidah prinsip-prinsip yang ditetapkan, sedangkan efek dakwah tergantung kepada hidayah Allah swt.

Abstract

Implementation of dakwah has some rules that are principle-policy principle that should be applied leh preachers, including messages, methods, and environmental mad'u. It was very humane. Rule prinsiplel missionary include the creation of harmony between softness and firmness, enjoining good and forbidding evil according to the capabilities of the order not to cause greater damage. Similarly, in terms of culture, the need for multicultural missionary principle which can take things from the good old local wisdom and reject new things that are not in accordance with Islam. There is no coercion in preaching, preachers are only required according to the rules of principle, that principles, while the propaganda effect depends on the guidance of Allah Almighty.
\end{abstract}

Kata Kunci: Kaidah, Dakwah, dan Fikih 


\section{Pendahuluan}

Gerakan dakwah adalah tugas mulia yang disyariatkan Allah swt. di muka bumi. Dakwah tidak terlepas dari beberapa kaidah yang harus dipedomani da'i yang dalam tugasnya sebagai orang pemberi pencerahan kepada masyarakat, terutama dalam membimbing manusia ke jalan iman dan takwa. Dakwah sering kali berhadapan dengan problematika masyarakat yang berkaitan dengan situasi dan kondisi mad'u, penyesuaian pesan dan metode dakwah, sehingga da'i harus kembali kepada kaidah yang ada. Demikian juga kemajuan masyarakat modern yang akrab dengan teknologi komunikasi dan informasi, dakwah akan memerlukan kaidahkaidah yang harus dipedomani. Perubahan sosial yang terjadi di masyarakat menjadi faktor lain yang tidak kalah pentingnya untuk mendorong pentingnya kaidah prinsif-prinsif dakwah.

Kajian tentang kaidah prinsif-prinsifdakwah masuk dalam bidang kajian pikih dakwah. Pikih dakwah dikelompokkan dalam wilayah pikih mu'amalah. Kaidah-kaidah yang mengatur hukum-hukum dan aturanaturan berdakwah akan memberi petunjuk dalam menyusun strategi dakwah, sehingga para da'i dapat mencapai tujuan maksimal melalui beberapa prinsif dan langkah-langkah strategis. Allah swt. mejelaskan beberapa petunjuk tentang metode dakwah dalam al-Qur'an anatara lain surat an-Nahlu ayat 125, yaitu berdakwah dengan prinsif hikmah, pengajaran yang baik dan berdebat (dengan ahli kitab) dengan cara yang lebih baik. Ayat tersebut menunjukkan betapa pentingnya kaidah prinsifprinsif dakwahlslam.

Para ulama dalam bidang pikih dakwah telah menguraikan panjang lebar kaidah-kaidah dakwah dimaksud agar dapat dipedomani oleh praktisi dakwah di lapangan. Istilah pikih dakwah mengemuka pada abad ke-20 dengan lahirnya buku pertama yang ditulis oleh Sayyid Quthub. Kitab ini merupakan intisari dari pemikiran teologi dakwah beliau sebagaimana ditemukan dalam Kitab Tafsir Fi zhilal al-Qur'an. ${ }^{1}$ Kerancuan dakwah dapat

'Sayyid Quthub, Figh Al-Da'wah Mawdlu'at fi Al-Da'wah wa Al-Harakat, Beirut, Muassasah ar-Risalah, 1970 hlm. 2. 


\section{Kamaluddin}

terjadi apabila tidak didasari oleh kaidah prinsif-prinsif yang benar. Para da'i yang berprofesi sebagai muballgh dituntut sebagai "balaagh" (orang yang menyampaikan pesan-pesan dakwah) sesuai ketentuan, sedangkan keberhasilannya membutuhkan "hidayah" dari Allah swt.

Aktivitas dakwah saat ini menunjukkan indikasi bahwa dakwah belum sepenuhnya didasarkan atas beberapa kaidah prinsifil sebagaimana telah digariskan dalam pikih dakwah. Realita ini menimbulkan efek yang tidak baik bagi pelaksanaan dakwah di masyarakat, sebagai contoh adanya radikalismeyang memaksakan amar ma'ruf dan nahi mungkar.Demikian juga multikulturalisme dan perubahan sosial sebagai efek dari kemajuan ilmu pengetahuan dan teknologi. Faktor-faktor tersebut menunjukkan bahwa kajian pikih dakwah tentang kaidah prinsif-prinsif dakwah menjadi sangat penting didiskusikan.

\section{Pikih Dakwah}

Pikih dakwah terdiri dari dua kata, yaitu kata Pikih dan dakwah. Penulis tidak menjelaskan secara detail kedua makna kata itu, tetapi langsung mengemukakan makna pikih dakwah. Pikih dakwah adalah ilmu tentang istimbat, yaitu mengambil sebuah hukum atau faidah untuk memahami aktivitas dakwah termasuk sejarah dakwah, sebab-sebabnya, rukun-rukunnya, berbagai cara berdakwah, sarana-sarananya, tujuantujuannya dan macam-macam hasil dari dakwah tersebut, dengan istimbat dan pemahaman dari Al-Qur'an dan Sunnah, sesuai dengan pemahaman para ulama salaf (terdahulu) yang sholeh. Sang pendakwah perlu menyampaikan materi dakwahnya denga cara yang baik, menyesuaikan dengan orang-orang yang didakwahi dan lingkungan sekitar, memperhatikan perbedaan bahasa dan segi-segi lainnya yang selalu berbeda². Hal ini sebagai pengamalan dari Firman Allah dalam surat Yusuf (12) ayat 108:

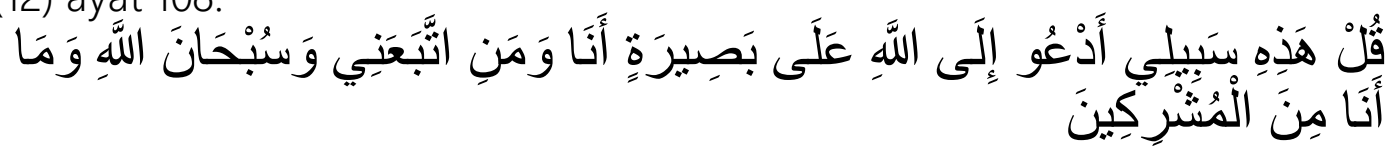

${ }^{2}$ Said Ali bin Wahf al Qahthani, Fiqh Ad-Dakwah Fi Shahih Al-Imam Al-Bukhari, Darul Kutub, 2002 hlm. 87. 
Katakanlah: "Inilah jalan (agama) ku, aku dan orang-orang yang mengikutiku mengajak (kamu) kepada Allah dengan hujjah yang nyata, Maha suci Allah, dan saya tidaklah termasuk dari golongan kaum musyrikin. ${ }^{3}$

Pikih dakwah dapat juga diartikan sebagai ilmu yang memberi kefahaman, pengetahuan, mengenali hak diri dan tanggungjawab sebagai seorang yang menyebarkan seruan Islam kepada semua manusia untuk mengajak mereka mengenali Allah. Dengan demikian,pikih dakwah dimaksudkan untuk mengajak atau menyeru manusia untuk mengamalkan ajaran Islam dengan prinsif dan strategi yang lebih sempurna.

Adapun yang membedakan pikih dakwah dengan ilmu dakwah adalah : ilmu dakwah membahas apa adanya tentang kegiatan dakwah, sedangkan pikih dakwah membahas apa yang seharusnya di lakukan dalam kegiatan dakwah. Jika teologi dakwah laksana motor yang berfungsi sebagai pendorong, maka ilmu dakwah adalah kendaraan beserta komponenya, dan pikih dakwah merupakan jalan beserta rambu- rambunya. Dengan kata lain, agar bersemangat dalam berdakwah, kita belajar teologi dakwah, untuk menemukan kondisi ril dakwah Islam kita mempelajari ilmu dakwah, dan supaya dakwah kita terarah dengan benar dibutuhkan kajian tentang pikih dakwah.

Sebagai tugas mulia yang diemban oleh para rasul, maka dakwah memiliki beberapa kaidah yang harus dipedomani oleh para pendakwah. Sesuai dengan perkembangan organisasi -oganisasi Islam yang bergerak dalam dakwah, kaidah-kaidah dakwah telah turut berkembang sesuai dengan falsafah dakwah masing-masing organisasi. Kaidah tersebut merupakan kesimpulan fatwa ulama tentang kaidah-kaidah dan strategi yang dianut oleh organisasi tersebut, seperti kesimpulan fatwa dakwah Nahdlatul Ulama, Muhammadiyah dan Majelis Ulama Indonesia. Fatwa ini menjadi kaidah-kaidah yang diterapkan sebagai kekhususan organisasi. ${ }^{4}$ Terdapat perbedaan kaidah antara beberapa organisasi, tetapi perbedaan tersebut tidak menyangkut masalah pokok,perbedaan hanya

${ }^{3}$ Departemen Agama RI, Al-Qur'an dan Terjemahnya (Diponegoro, 2005), hlm. 198

${ }^{4}$ Mohlm. Ali Aziz, IImu Dakwah, Kencana Jakarta, 2009 hlm. 162 


\section{Kamaluddin}

dalam masalah cabang. Kaidah-kaidah dakwah pokok tidak terdapat perbedaan. Bagaimana kaidah-kaidah dan prinsif-prinsif pokok strategi dakwah yang berlaku secara umum bagi da'i dan masyarakat secara umum inilah yang akan dikemukakan dalam makalah ini.

\section{Kaidah Prinsif-PrinsifDakwah}

Fikih dakwah membahas beberapa kaidah pokok yang terdiri dari aturan-aturan atau hukum-hukum yang harus ditetapkan dalam operasional dakwah sesuai dengan al-Qur'an dan al-Hadis. Kaidah-kaidah pikhiyah tersebut terbagi kepada dua bentuk, yaitu:

1. Kaidah-kaidah pikih untuk dakwah (al-qawa'idul fiqhiyah li ad-da'wah) yang dijadikan sebagai instrumen dalam menentukan hukum-hukum atau aturan-aturan yang berkenaan dengan dakwah.

2. Kaidah prinsif-prinsif dakwah (al-qawa'idu li ad-da'wah), yaitu beberapa kaidah yang dijadikan sebagai prinsif-prinsif dalam menyusun strategi, metode atau tehnik dalam pelaksanaan dakwah. Kaidah kedua inilah yang menjadi fokus pembahasan dalam makalah ini.

Jum'ah Amin Abdul Aziz telah menguraikan secara detail tentang kaidah prinsif-prinsif pelaksanaan dakwah tersebut yang mencakup komponen-komponen dakwah, yaitu komponen da'i, komponen materi, mad'u, metode, situasi dan kondisi lingkungan dakwah, sebagai berikut: ${ }^{5}$

\section{Kaidah Pertama:Prinsif yang berkenaan dengan da'i}

1. Memberi keteladanan sebelum berdakwah (al-qudwah qobla ad-da'wah).

Seorang da'i adalah contoh teladan di masyarakat, keteladanannya dapat diteladani dan dapat juga mengangkat mutu dan kewibawaannya dalam mengajak masyarakat kepada kebaikan. Keteladanan da'i berarti memulai kebaikan dari diri sendiri kemudian mengajak orang lain untuk mengikutinya. Keteladanan mencakup iman, amal, akhlak dan sifat-sifat terpuji.

2. Seorang da'i hendaklah muridnya guru, bukan muridnya buku.

5Jum'ah Amin Abdul Aziz, Fiqih Dakwah, Terjemahan Abdus Salam Masykur, Era Intermedia Solo, Tahun 2000 hlm. 69 
Jum'ah Amin mengemukakan bahwa da'i lebih utama belajar langsung kepada guru atau ulama dari pada belajar mmelalui bukunya guru. Ini didasarkan kepada hadis nabi saw. yang diriwayatkan oleh Imam Bukari yang menyatakan bahwa Allah swt. mencabut ilmu bukan mengangkat ilmu itu dari manusia, tetapi adalah dengan cara mencabut nyawa ulama. Maka ketika tidak ada lagi orang berilmu, manusia akan mengangkat pemimpin dari kalangan orang bodoh yang memberi fatwa menyesatkan ${ }^{6}$. Buku adalah hasil karya guru yang dituliskan. Bagi para da'i yang bermukim jauh dari kediaman guru (ulama) yang tidak mungkin didatangi secara langsung, maka da'i dapat juga belajar kepada gurunya melalui buku.

Berkenaan dengan prinsif-prinsif yang berkaitan da'i, para ulama telah menjelaskan beberapa kriteria dan kometensi da'i. Da'i disyaratkan memiliki beberapa kompetensi, antara lain kompetensi Subtantif dan kompetensi metodologis. Pendapat lain mengatakan bahwa seorang da'i hendaknya memiliki kekuatan intelektual (wawasan keilmuan), keterampilan (skil), kekuatan moral (akhlak) dan kekuatan spritual. ${ }^{7}$

Fawwaz bin Hulayyil menjelaskan kompetensi da'i sebagai berikut:

1. Keikhlasan dalam berdakwah.

2. Dakwah dengan ilmu dan bashiroh dalam agama.

3. Sikap sabar dan santun dalam menghadapi setiap cobaan. ${ }^{8}$

\section{Kaidah Kedua: Prinsif Penetapan Metode Dakwah}

1. Mengikat hati sebelum membebani (at-ta'lif qobla at-ta'rif).

Para ahli dakwah menetapkan metode dakwah berdasarkan surat an-Nahlu ayat 125 yang menyatakan bahwa dakwah Islam disampaikan dengan cara hikmah, pengajaran (nasihat) yang baik dan berdebat dengan cara yang lebih baik. Ini menunjukkan bahwa metode dakwah Islam memiliki prinsif dakwah humanis. Dakwah bukanlah beban tetapi kebutuhan. Dakwah penuh kelembutan, penuh pertimbangan, tidak

${ }^{6}$ Imam Al-Bukhari, Shahih Bukhari, Toha Putra Semarang t.t. hlm. 33-34

${ }^{7}$ A. Ilyas Ismail, Filsafat Dakwah, Kencana Prenada Media Group, Jakarta 2013 hlm. 79

${ }^{8}$ Fawwaz bin Hulayyil as-Suhaimi, Begini Seharusnya Berdakwah, Terjemahan Beni Sarbeni LC. Darul Haq Jakarta, 2013 hlm. 29 
Kamaluddin

memaksakan serta selalu menjaga kerahasiaan mad'u. Firman Allah dalam surat Ali Imran (3) ayat 159.

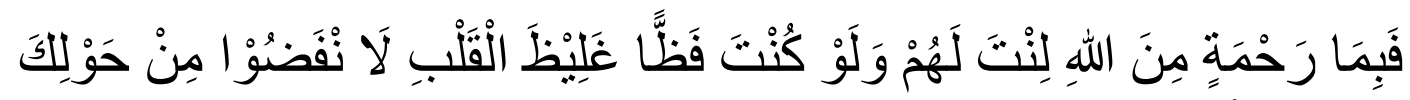

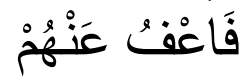

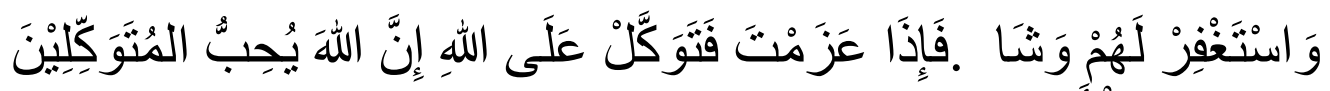

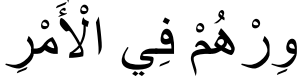

"Maka disebabkan rahmat dari Allah-lah kamu Berlaku lemah lembut terhadap mereka. Sekiranya kamu bersikap keras lagi berhati kasar, tentulah mereka menjauhkan diri dari sekelilingmu. karena itu ma'afkanlah mereka, mohonkanlah ampun bagi mereka, dan bermusyawaratlah dengan mereka dalam urusan itu9 ${ }^{9}$. kemudian apabila kamu telah membulatkan tekad, Maka bertawakkallah kepada Allah. Sesungguhnya Allah menyukai orang-orang yang bertawakkal kepada-Nya."10

2. Mengenalkan sebelum memberi beban (at-ta'rif qobla at-ta'lif).

Dakwah dimulai dari askpek kognitif sebelum aspek afektif dan psikomotor, yaitu memberikan informasi dan konfirmasi kepada mad'u sebelum diber kewajiban menjalankan ajaran Islam. Dengan bekal ilmu pengetahuan yang dimiliki seorang mad'u akan dapat mengamalkan ajaran Islam dengan baik. Frirman Allah dalam surat Muhammad (47) ayat 19.

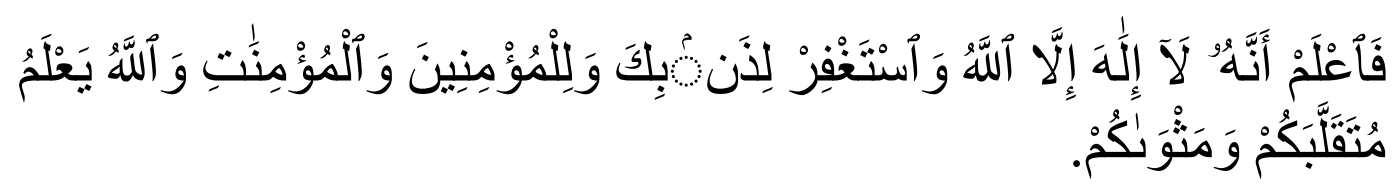

"Maka ketahuilah, bahwa Sesungguhnya tidak ada llah (sesembahan, Tuhan) selain Allah dan mohonlah ampunan bagi dosamu dan bagi (dosa)

${ }^{9}$ Maksudnya: urusan peperangan dan hal-hal duniawiyah lainnya, seperti urusan politik, ekonomi, kemasyarakatan dan lain-lainnya.

10 Departemen Agama Rl, Al-Qur'an dan Terjemahnya, CV. Diponegoro, 2005 hlm. 56 
orang-orang mukmin, laki-laki dan perempuan. dan Allah mengetahui tempat kamu berusaha dan tempat kamu tinggal."11

3. Memudahkan bukan menyulitkan (at-taysir la at-ta'sir).

Strategi dakwah Islam adalah memudahkan dan bukan mempersulit urusan. Firman Allah dalam surat al-Baqarah (2) ayat 185.

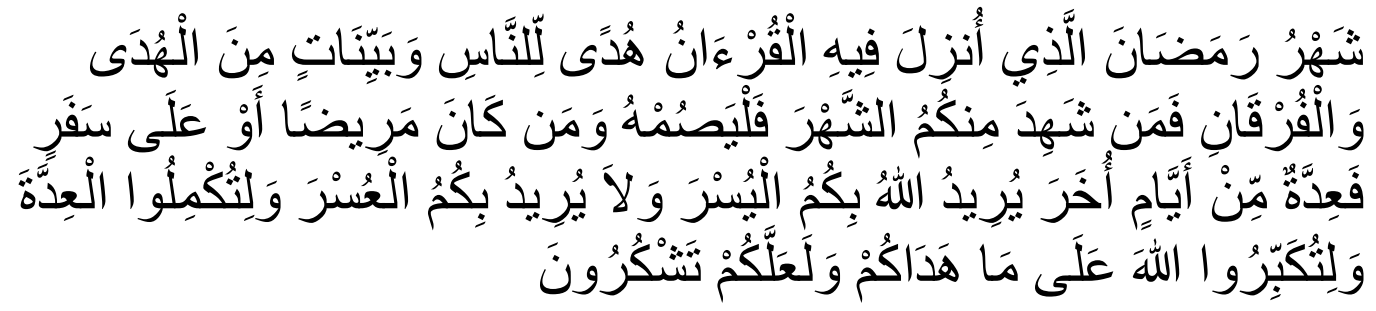

"(Beberapa hari yang ditentukan itu ialah) bulan Ramadhan, bulan yang di dalamnya diturunkan (permulaan) A/ Quran sebagai petunjuk bagi manusia dan penjelasan-penjelasan mengenai petunjuk itu dan pembeda (antara yang hak dan yang bathil). karena itu, Barangsiapa di antara kamu hadir (di negeri tempat tinggalnya) di bulan itu, Maka hendaklah ia berpuasa pada bulan itu, dan Barangsiapa sakit atau dalam perjalanan (lalu ia berbuka), Maka (wajiblah baginya berpuasa), sebanyak hari yang ditinggalkannya itu, pada hari-hari yang lain. Allah menghendaki kemudahan bagimu, dan tidak menghendaki kesukaran bagimu. dan hendaklah kamu mencukupkan bilangannya dan hendaklah kamu mengagungkan Allah atas petunjuk-Nya yang diberikan kepadamu, supaya kamu bersyukur."12

4. Memberi pemahaman bukan mendikte (at-tafhim la at-talqin).

11Departemen Agama Rl, Al-Qur'an dan Terjemahnya, CV. Diponegoro, 2005 hlm. 406

${ }^{12}$ Departemen Agama RI, Al-Qur'an dan Terjemahnya, CV. Diponegoro, 2005 hlm. 22 
Seorang da'i tidaklah orang yang hanya menyampaikan pesan dengan cara mendikte orang, tetapi hendaklah pesan yang disampaikan dapat memberi pemahaman tentang maksud pesan tersebut. Penyampaian pesan yang jelas dan detail akan memudahkan mad'u menerima dan memahaminya. Penerimaan mad'u akan pesan-pesan dakwah yang kurang jelas akan dapat menimbulkan kesalah pahaman dalam menerima pesan sehingga maksud dan tujuan dakwah tidak tercapai. Firman Allah dalam surat al-Anbiya' (21) ayat 78-79.

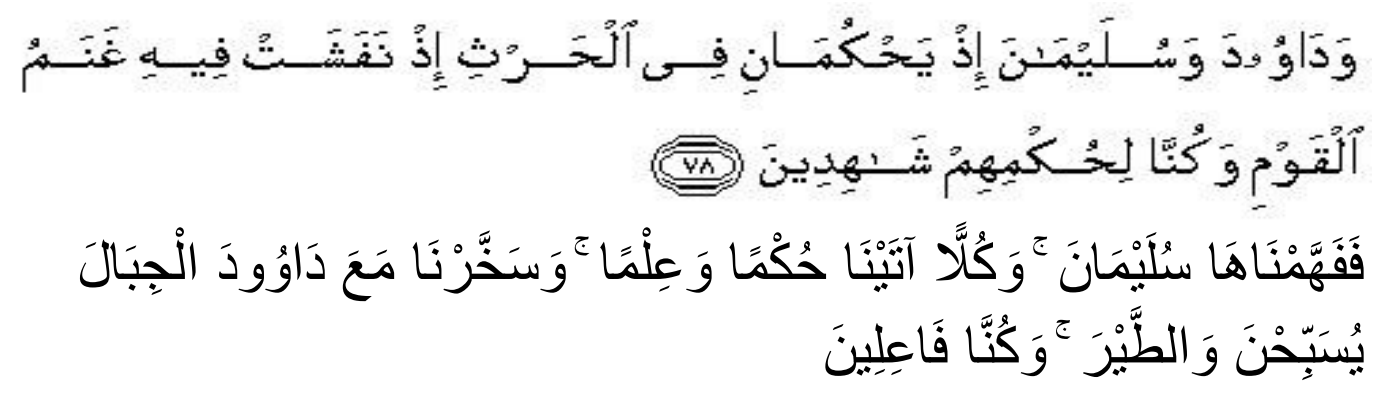

"dan (ingatlah kisah) Daud dan Sulaiman, di waktu keduanya memberikan keputusan mengenai tanaman, karena tanaman itu dirusak oleh kambingkambing kepunyaan kaumnya. dan adalah Kami menyaksikan keputusan yang diberikan oleh mereka itu, (78). Maka Kami telah memberikan pengertian kepada Sulaiman tentang hukum (yang lebih tepat)'13; dan kepada masing-masing mereka telah Kami berikan Hikmah dan ilmu dan

${ }^{13}$ Menurut riwayat Ibnu Abbas bahwa sekelompok kambing telah merusak tanaman di waktu malam. Maka yang Empunya tanaman mengadukan hal ini kepada Nabi Daud a.s. Nabi Daud memutuskan bahwa kambing-kambing itu harus diserahkan kepada yang Empunya tanaman sebagai ganti tanam-tanaman yang rusak. tetapi Nabi Sulaiman a.s. memutuskan supaya kambing-kambing itu diserahkan Sementara kepada yang Empunya tanaman untuk diambil manfaatnya. dan orang yang Empunya kambing diharuskan mengganti tanaman itu dengan tanam-tanaman yang baru. apabila tanaman yang baru telah dapat diambil hasilnya, mereka yang mepunyai kambing itu boleh mengambil kambingnya kembali. putusan Nabi Sulaiman a.s. ini adalah keputusan yang tepat. 
telah Kami tundukkan gunung-gunung dan burung-burung, semua bertasbih bersama Daud. dan kamilah yang melakukannya(79). ${ }^{14}$

5. Mendidik bukan mempermalukan (at-tarbiyah la at-ta'riyah).

Berdakwah dilakukan dengan cara mendidik mad'u dengan ajaran Islam. Dalam menghadapi mad'u yang beraneka ragam bentuk dan karakternya seorang da'i hendaklah menghindari hal-hal yang dapat menyinggung perasaan mad'u dengan cara membuka aib dan kesalahannya didepan khalyak. Dengan demikian si mad'u tidak merasa dipermalukan. Firman Allah surat Yusuf (12) ayat 36-37.

- $\triangle$ H

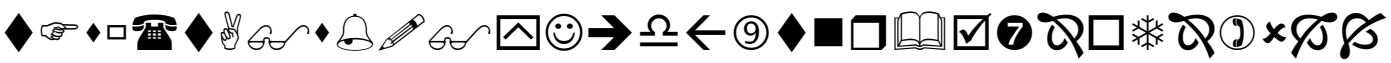

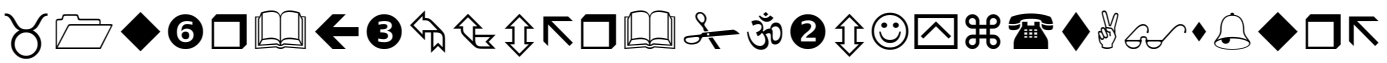

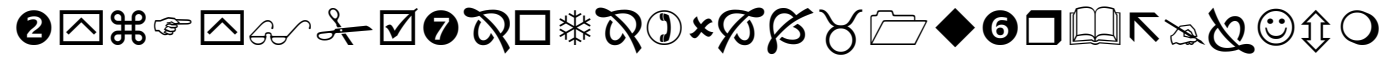

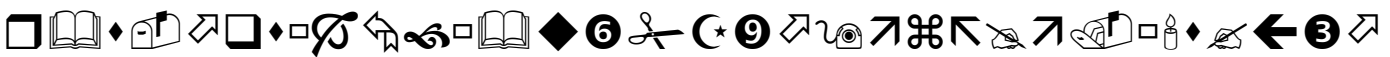
2人 כ20as \&

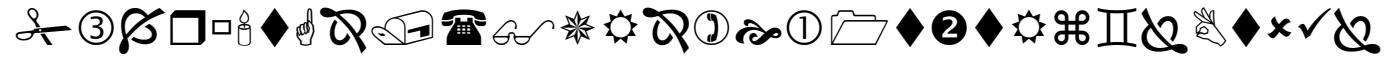

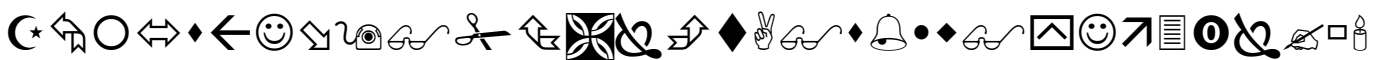

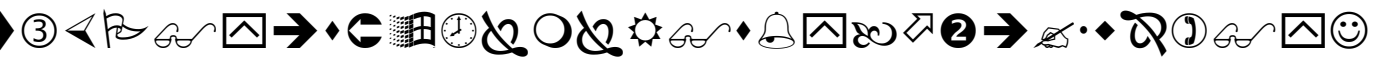

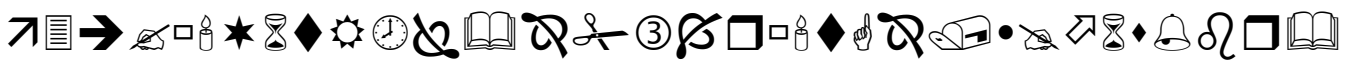

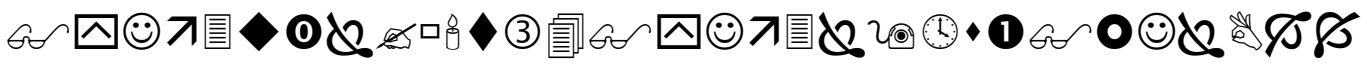

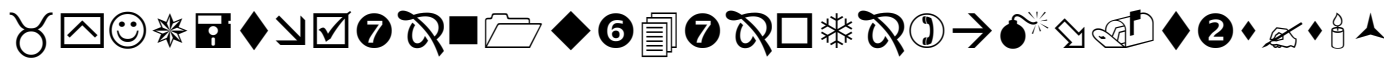

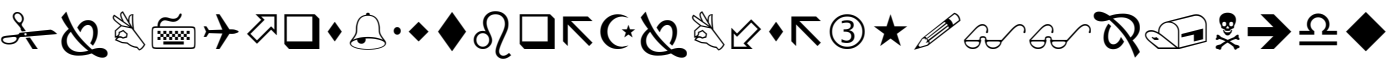

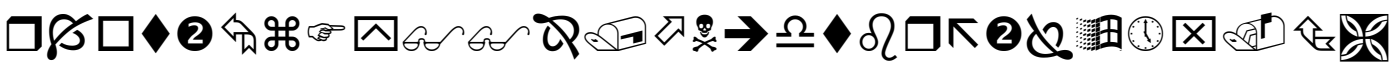

36. dan bersama dengan Dia masuk pula ke dalam penjara dua orang pemuda ${ }^{15}$. berkatalah salah seorang diantara keduanya: "Sesungguhnya aku bermimpi, bahwa aku memeras anggur." dan yang lainnya berkata:

${ }^{14}$ Departemen Agama RI, A/-Qur'an dan Terjemahnya, CV. Diponegoro, 2005 hlm. 262

${ }^{15}$ Menurut riwayat dua orang pemuda itu adalah pelayan-pelayan raja; seorang pelayan yang mengurusi minuman raja dan yang seorang lagi tukang buat roti. 


\section{Kamaluddin}

"Sesungguhnya aku bermimpi, bahwa aku membawa roti di atas kepalaku, sebahagiannya dimakan burung." berikanlah kepada Kami ta'birnya; Sesungguhnya Kami memandang kamu Termasuk orang-orang yang pandai (mena'birkan mimpi).

37. Yusuf berkata: "tidak disampaikan kepada kamu berdua makanan yang akan diberikan kepadamu melainkan aku telah dapat menerangkan jenis makanan itu, sebelum makanan itu sampai kepadamu. yang demikian itu adalah sebagian dari apa yang diajarkan kepadaku oleh Tuhanku. Sesungguhnya aku telah meninggalkan agama orang-orang yang tidak beriman kepada Allah, sedang mereka ingkar kepada hari kemudian. ${ }^{16}$

Dalam mendidik mad'u seorang da'i hendaklah memperhatikan latar belakang kehidupan setiap individu. Rasulullah saw. dalam dakwahnya senantiasa memperhatikan kondisi latar belakang kejiwaan mad'unya. Prinsif ini terlihat dari beberapa sikap beliau anatara lain:

a. Perbedaan nsehat beliauterhadap beberapa orang yang berbeda latar belakangnya.

b. Perbedaan jawab dan fatwanya pada pertanyaan yang ditujukan oleh beberapa orang yang berbeda.

c. Perbedaan sikap dan perilakunya terhadap orang-orang yang berinteraksi dengan mereka.

d. Perbedaan perintah dan pembebanan terhadap orang yang berbeda serta dengan kemampuan dan kapasitas yang berbeda.

e. Penerimaannya terhadap sebahagian sikap atau perilaku seseorang yang tidak dia terima dari orang yang berbeda. ${ }^{17}$

\section{Kaidah Ketiga: Prinsif Pengelolaan Pesan}

1. Penyampaian pesan dakwah secara bertahap (at-tadarruj fi at-taklif).

Pemberian pesan dakwah merupakan bahagian penting dalam dakwah karena setiap pesan yang disampaikan pada prinsifnya adalah pemberian beban yang harus diamalkan oleh mad'u. Tahapan dakwah

\footnotetext{
${ }^{16}$ Departemen Agama RI, Al-Qur'an dan Terjemahnya, CV. Diponegoro, 2005 hlm.
} 12

${ }^{17}$ Musthafa Malaikah, Manhaj Dakwah Yusuf Qaradlawi, Terjemahan Samson Rahman, Pustaka al-Kautsar Jakarta tahun 2001 hlm. 43-44. 
dalam pemberian pesan dakwah sesuai dengan prinsif turunnya alQur'an dengan cara tahap demi tahap. Hal ini dimaksudkan untuk penyesuaian pembebanan dengan kemampuan mad'u sehingga masyarakat tidak terkesan memberatkan. Firman Allah dalam surat AlFurqon (25) ayat 32-33.

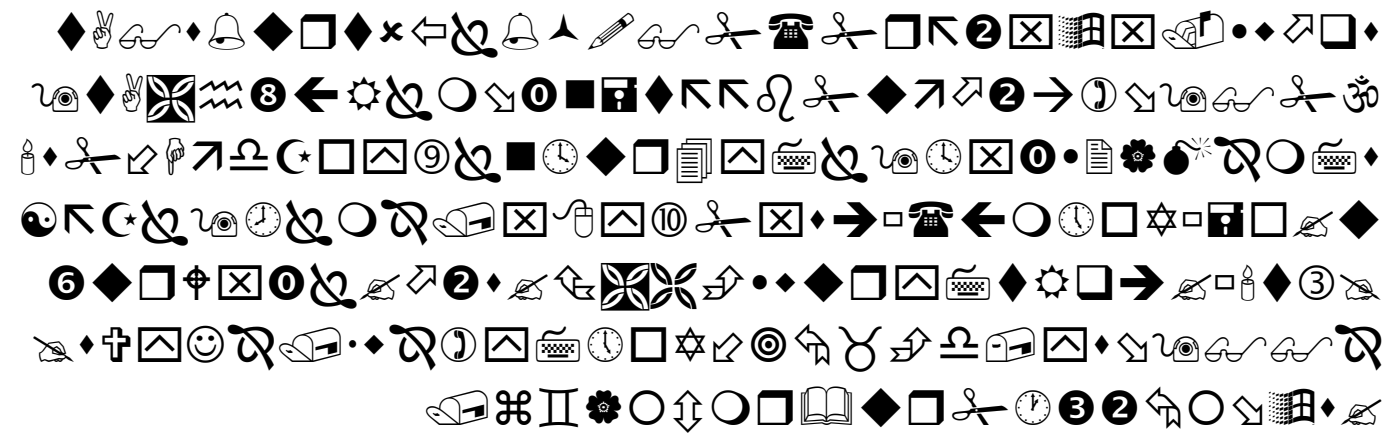

32. berkatalah orang-orang yang kafir: "Mengapa Al Quran itu tidak diturunkan kepadanya sekali turun saja?"; demikianlah ${ }^{18}$ supaya Kami perkuat hatimu dengannya dan Kami membacanya secara tartil (teratur dan benar).

33. tidaklah orang-orang kafir itu datang kepadamu (membawa) sesuatu yang ganjil, melainkan Kami datangkan kepadamu suatu yang benar dan yang paling baik penjelasannya. ${ }^{19}$

Jum'ah Amin mengatakan beberapa prinsif dakwah yang dapat meringankan beban masyaraka mad'u, sebagai berikut:

a. Boleh meninggalkan kemaslahatan untuk menghindari kerusakan.

b. Boleh tidak mengingkari suatu kemungkaran sementara waktu, karena takut terjadi kemungkaran yang lebih besar.

c. Menjauhi hal-hal yang dipandang buruk dan membahayakan masyarakat.

${ }^{18}$ Maksudnya: Al Quran itu tidak diturunkan sekaligus, tetapi diturunkan secara berangsur-angsur agar dengan cara demikian hati Nabi Muhammad s.a.w menjadi kuat dan tetap.

${ }^{19}$ Maksudnya: Setiap kali mereka datang kepada Nabi Muhammad s.a.w membawa suatu hal yang aneh berupa usul dan kecaman, Allah menolaknya dengan suatu yang benar dan nyata.Departemen Agama Rl, Al-Quran dan Terjemahnya, CV. Diponegoro, 2005 hlm. 289 
d. Menetapkan prioritas dakwah dari yang paling penting menuju yang cukup penting dan seterusnya dipandang sebagai tindakan menghindari yang negatif dan mendatangkan yang positif. 20

2. Masalah yang Pokok sebelum Cabang (al-Ushulu qobla al-Furu)

Prinsif ini berdasarkan firman Allah dalam surat Ali Imran (3) ayat 7.

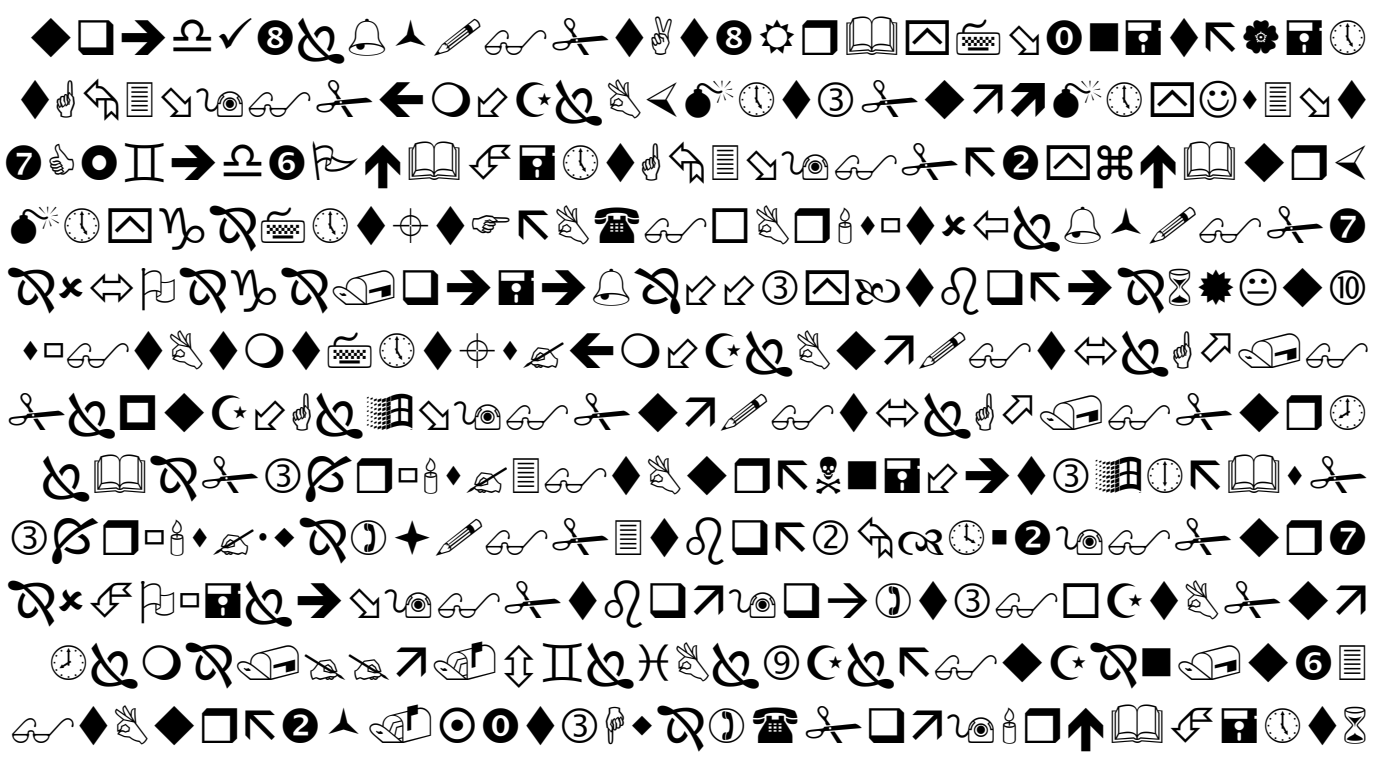

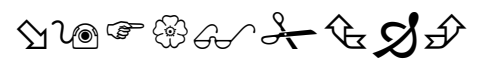

7. Dia-lah yang menurunkan Al kitab (Al Quran) kepada kamu. di antara (isi) nya ada ayat-ayat yang muhkamaat ${ }^{21}$, Itulah pokok-pokok isi Al qur'an dan yang lain (ayat-ayat) mutasyaabihaat ${ }^{22}$. Adapun orang-orang yang dalam hatinya condong kepada kesesatan, Maka mereka mengikuti sebahagian ayat-ayat yang mutasyaabihaat daripadanya untuk

20 Jum'ah Amin, Fiqih Dakwah, Penerjemah Abdus Salam Masykur, Eralntermedia, $2000 \mathrm{hlm} .592$

${ }^{21}$ Ayat yang muhkamaat ialah ayat-ayat yang terang dan tegas maksudnya, dapat dipahami dengan mudahlm.

${ }^{22}$ Termasuk dalam pengertian ayat-ayat mutasyaabihaat: ayat-ayat yang mengandung beberapa pengertian dan tidak dapat ditentukan arti mana yang dimaksud kecuali sesudah diselidiki secara mendalam; atau ayat-ayat yang pengertiannya hanya Allah yang mengetahui seperti ayat-ayat yang berhubungan dengan yang ghaib-ghaib misalnya ayat-ayat yang mengenai hari kiamat, surga, neraka dan lain-lain. 
menimbulkan fitnah untuk mencari-cari ta'wilnya, Padahal tidak ada yang mengetahui ta'wilnya melainkan Allah. dan orang-orang yang mendalam ilmunya berkata: "Kami beriman kepada ayat-ayat yang mutasyaabihaat, semuanya itu dari sisi Tuhan kami." dan tidak dapat mengambil pelajaran (daripadanya) melainkan orang-orang yang berakal. ${ }^{23}$

Ayat tersebut menjelaskan bahwa menyampaikan pesan dakwah tentang ayat-ayat muhkamat lebih didahulukan daripada ayat-ayat yang mutasyabihat, masalah tauhid lebih didahulukan dari masalah lain. Demikian juga dalam masalah amal-amal yang wajib, lebih dahulu disampaikan dari pada yang amalan yang sunat-sunat. Masalah penting didahulukan dari masalah biasa. Persoalan yang besar diutamakan dari persoalan yang kecil. Contoh : kalangan mad'u yang membutuhkan materi pesan tentang shalat wajib lebih didahulukan dari mad'u yang membutuhkan materi tentang shalat sunat dluha.

3. Pesan tentang membesarkan hati lebih dahulu dari pada memberi ancaman (at-Targhib qobla at-tarhib. Prinsif seperti ini banyak ditemukan dalam al-Qur'an antara lain dalam surat Muhammad (26) ayat 7-8.

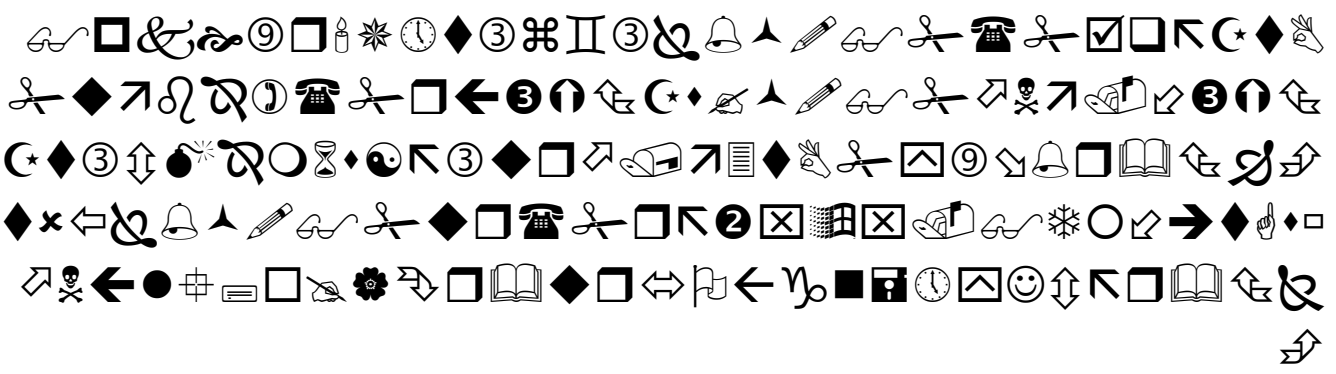

7). Hai orang-orang mukmin, jika kamu menolong (agama) Allah, niscaya Dia akan menolongmu dan meneguhkan kedudukanmu.

8). dan orang-orang yang kafir, Maka kecelakaanlah bagi mereka dan Allah menyesatkan amal-amal mereka. ${ }^{24}$

Dalam ayat tersebut dengan jelas terlihat bahwa pesan kebaikan yang diterima oleh orang mukmin (at-targhib) lebih dahulu disampaikan dari pesan ancaman bagi orang kafir karena kesesatan mereka (at-tarhib).

\footnotetext{
23 Departemen Agama RI, Al-Qur'an Dan Terjemahnya,cv. Diponegoro, 2005 hlm. 39

${ }^{24}$ Departemen Agama RI, Al-Qur'an Dan Terjemah,CV. Diponegoro 2005 hlm. 405
} 


\section{Kamaluddin}

Dengan demikian, seorang da'i hendaknya lebih mengutamakan pesanpesan yang dapat membangkitkan semangat dan gairah mad'u untuk mengamalkan kebaikan dengan menyampaikan motivasi tentang amal shaleh dan ganjaran yang diterimanya. Pada prinsifnya apabila seseorang telah mengamalkan kebaikan seperti shalat, puasa, zakat dan haji, maka dengan sendirinya dia akan terjauh dari kejahatan.

Dari segi lain, seorang da'i yang terlalu banyak mencela atau mengancam orang kafir, musyrik dan orang-orang fasik dengan berbagai pesan yang berbentuk ancaman, siksaan dan hukuman di dunia dan akhirat, mereka dikhawatirkan justru cenderung akan membenci dakwah. Bagi ummat Islam yang melakukan kemungkaran sekalipun tidak dianjurkan mencela aibnya. Sebab mengungkap dan mencela aib seseorang disebut ghibah. Rasulullah saw. dalam menerapkan hukuman bagi wanita yang berzina disebutkan dalam hadis bahwa Beliau melarang ummat Islam untuk mencaci dan membeberkan aibnya.

\section{Kaidah Keempat: Prinsif Menghadapi Mad'u}

Dakwah Islam ditujukan kepada seluruh ummat manusia, baik laki-laki maupun perempuan, penguasa atau rakyat, orang terdidik atau orang awam, kaum munafik atau orang shaleh, kepada kaum muslimin atau non muslim. Seorang da'i hendaklah memperhatikan mad'unya dari aspek sosiologis, psikologis maupun budaya yang dianutnya. Fawwaz bin Hulayyil as-Suhaimi mengemukakan kaidah yang berhubungan dengan beberapa prinsif menghadapi perbedaan mad'u sebagai berikut:

1. Prinsif menjaga perbedaan antara berdakwah kepada kaum muslimin dan non muslimin.

Dakwah kepada non muslim dimulai dengan dakwah tauhid kepada Allah swt. Amal yang dilakukan oleh mereka tidak akan diterima sebelum bersaksi kepada Allah dan Rasul-Nya.

2. Menjaga perbedaan antara berdakwah kepada orang awam dengan ahli hawa'

3. Menjaga perbedaan antara berdakwah kepada penguasa dengan rakyat. 
4. Menjaga perbedaan budaya, status ekonomi, usia dan tingkat pendidikan.

Selain itu terdapat juga kaidah yang mengatakan bahwa:

1. Al-Mamat wal- Hayat

Mad'u yang usianya sudah tua atau siapapun yang diperkirakan ajalnya sudah dekat (al-mamat) lebih diprioritaskan dari pemuda. Orang yang sudah tua dan sakit yang memerlukan materi tentang cara bertayammum untuk shalat, lebih diutamakan dari pada pemuda yang sehat dan segar bugar.

2. Al-Amir wal-Wazir

Pemimpin tertinggi (al-Amir) dalam suatu wilayah atau organisasi mendapat prioritas dari bawahan atau anggotanya. Pimpinan tersebut adalah pembuat kebijakan (policy maker) yang menentukan dalam suatu wilayah. Prioritas ini diberikan dengan harapan bahwa kesalehan dan ke'alimannya akan mempengaruhi bawahan (al-Wazir). Gubernur yang membutuhkan pengetahuan tentang ekonomi syari'ah harus didahulukan dari pada camat disebuah kecamatan.

3. Mukallaf wa Ghairu Mukallaf

Berdakwah kepada orang dewasa (mukallaf) didahulukan dari pada anakanak (ghairu mukallaf), Setiap orang dewasa wajib melaksanakan mandi wajib ketika junub, maka mereka lebih di dahulukan belajar cara mandi wajib dari pada anak- anak yang belum dewasa.

4. Mu'allaf wa Ghairu Mu'allaf.

Non-muslim yang baru masuk Islam (mu'allaf) didahulukan dari orang yang sudah lama msuk Islam (ghairu mu'allaf). Diskusi tentang akidah Islam lebih diutamakan kepada mu'allaf tersebut dari pada kepada seorang kiyai (ghairu mu'allaf).

\section{Kaidah Kelima: Prinsif Memperhatikan Lingkungan Dakwah}

1. Menyesuaikan dakwah Islam dengan perkembangan zaman.

Kondisi kaummuslimin pada masa awal Islam berbeda dengan kondisi umat zaman sesudahnya sampai dengan masa sekarang. Kondisi 
ini telah djelaskan Nabi saw. dalam beberapa hadis, antara lain Beliau mengatakan dalam hadis riwayat Muslim:

"Sesungguhnya tidak ada seorang nabipun sebelumku, melainkan mereka menunjukkan ummatnya kepada kebaikan yang dia ketahui baik bagi mereka, dan memberikan peringatan kepada mereka suatu kejelekan yang dia ketahui buruk bagi mereka dan sesungguhnya ummat kalian in, keselamatannya dia jadikan diawalnya, sementara orang-orang yang ada di akhirnya akan ditimpa dengan berbagai musibah dan berbagai perkara yang kalian ingkari, lalu datanglah fitnah yang sebagian darinya akan menjadikan yang lain (terasa) ringan. "25

Hadis ini menjelaskan bahwa perkembangan zaman membawa ummat menuju kondisi yang lebih buruk dengan semakin merebaknya fitnah, bid'ah, permusuhan dan wahan (cinta dunia dan benci kematian). Demikian juga dampak kemajuan teknologi informasi bagi ummat Islam, di samping memiliki dampak positif, terdapat juga dampak negatif. Prinsif dakwah dalam menghadapi situasi dan kondisi ini adalah:

a. Dakwah Islam tidak mungkin dipaksakan mencapai sesuatu yang tidak mungkin dicapai seperti halnya pada masa shabat nabi saw.;

b. Dakwah Islam tetap terjaga kemurniannya sehingga tidak sampai kehilangan jati diri karena penyesuaian diri dengan perkembangan zaman;

c. Dakwah Islam harus memanfaatkan perkembangan teknologi informasi untuk kemajuan dakwah dalam wawasan global.

Rasul saw. memberi pegangan hidup bagi kaum muslimin yang hidup di zaman sekarang dalam salah satu hadis:

"Sesungguhnya akan merebak (setelahku) sikap mementingkan diri sendiri dan berbagai macam perkara yang kalian ingkari." Para sahabat bertanya: "Wahai Rasulullah apakah yang anda perintahkan kepada seseorang dari kami yang menjumpainya?" Beliau menjawab: "Tunaikanlah kewajiban kalian dan mintalah hak kalian kepada Allah."26

${ }^{25}$ Muslim bin al-Hajjaj,Shahih Muslim, Beirut Dar al-Fikri 1988 no. 1844

${ }^{26}$ Muslim Al-Hajjaj, ShahihMuslim, Beirut Dar al-Fikri 1988, no. 1843 
2. Prinsif penyesuaian dakwah dengan sosial- budaya masyarakat.

Para nabi Allah diutus kepada kaumnya membawa ajaran tauhid dan membawa ajaran yang sesuai dengan kodisi sosial mereka. Firman Allah dalam surat Ibrahim (14) ayat 4.

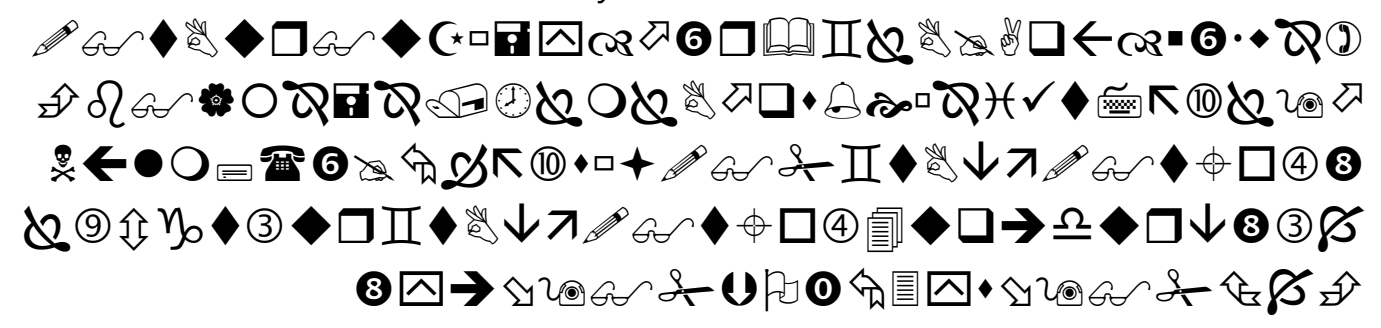

4) Kami tidak mengutus seorang rasulpun, melainkan dengan bahasa kaumnya27, supaya ia dapat memberi penjelasan dengan terang kepada mereka. Maka Allah menyesatkan ${ }^{28}$ siapa yang Dia kehendaki, dan memberi petunjuk kepada siapa yang Dia kehendaki. dan Dia-lah Tuhan yang Maha Kuasa lagi Maha Bijaksana. ${ }^{29}$

Prinsif penyesuaian dakwah dengan bentukkemungkaran yang dilakukan ummat digambarkan al-Qur'an antara lain seperti dakwah nabi Sy'aib yang membawa pesan-pesan tauhid yang murni kepada ummat yang selalu melakukan penipuan terus-menerus dalam perdagangan mereka, lalu Syu'aib mengajak mereka supaya transaksi dengan kejujuran dalam timbangan dan takaran. (Q.S. Asy-Syu'ara ayat 181). Demikian juga nabi Luth as. diutus untuk mengajak kaumnya kepada tauhid dan supaya meninggalkan homoseksual. (Q.S. Al-A'raf ayat 80-81). Rasul saw. ketika menulis surat dakwah ke Romawi, maka dikatakanlah :"Sesungguhnya

${ }^{27} \mathrm{Al}$ Qur'an diturunkan dalam bahasa Arab itu, bukanlah berarti bahwa Al Qu'an untuk bangsa Arab saja tetapi untuk seluruh manusia.

${ }^{28}$ Disesatkan Allah berarti: bahwa orang itu sesat berhubung keingkarannya dan tidak mau memahami petunjuk-petunjuk Allahlm. dalam ayat ini, karena mereka itu ingkar dan tidak mau memahami apa sebabnya Allah menjadikan nyamuk sebagai perumpamaan, Maka mereka itu menjadi sesat.

29 Departemen Agama Rl, A/-Qur'an Dan Terjemah, CV. Diponegoro 2005 hlm. 203 


\section{Kamaluddin}

mereka tidak akan membaca surat tanpa stempel", maka beliaupun membuat stempel dari perak. ${ }^{30}$

Hadis dan beberapa ayat di atas menunjukkan bahwa prinsif dakwah termasuk penyesuaian pesan dengan masalah yang menimpa mad'u agar mereka keluar dari keterbelakangan menuju kemajuan. Integrasi dakwah dengan budaya masyarakat yang semakin maju dan multikultural akan mengangkatke'arifan lokal dalam kontek sosialisasi dakwah humanis. Kaidah yang berkenaan dengan hal ini ialah : "Meninggalkan kebiasaan lama yang tidak baik dan mengambil hal baru yang lebih baik."

Prinsif lain yang berhubungan dengan kaidah ini ialah penyesuaian pesan dakwah dengan tingkat kecerdasan mad'u yang dihadapinya. Prinsif ini menuntut da'i akan kompetensi psikologi, antropoligi dan sosiologi, komunikasi dan ilmu hukum agar dapat berbicara dengan mad'u sesuai dengan tingkat kecerdasan, budaya dan kedudukansosial mereka. Kemajuan teknologi informasi mengakibatkan tingginya peradaban manusia, masyarakat mengetahui informasi global, semakin tingginya laju transformasi sosial serta terjadinya perubahan gaya hidup masyarakat. ${ }^{31}$

3. Penyesuaian dakwah dengan kondisi sosial- politik

Ulama telah banyak memberi penjelasan dan ijtihad dalam penyesuaian dakwah dengan sosial-politik suatu negara.Ummat Islam tidak seluruhnya berdomisili di negara Islam, oleh karena itu bagaimanakah prinsif dakwah dalam menyikapi penguasa dan falsafah negara yang bukan berdasarkan syariah. Ibnu Taimiyah mengemukakan kewajibkan amar ma'ruf nahi mungkar, sementara hal itu tidak mungkin tanpa kekuatan dan kepemimpinan, demikian juga dalam penegkan kewajiban lainnya seperti jihad, penegakan ke'adilan, perayaan Islam,

30 Imam Bukhari, Shahih Bukhari, Toha Putra Semarang, no. 1395

${ }^{31}$ Syukur Kholil, Dampak Teknologi Informasi Terhadap Pribadi Remaja, dalam HLM. Abdullah, Dakwah Humanis, Citapustaka Media Bandung, 2014 hlm. 231. 
menegakkan hukuman syari'ah yang semuanya tidak sempurna kecualidengan kekuatan dan kepemimpinan".32

Bagi ummat Islam yang hidup dalam suatu negara yang bukan Islam atau menjadi masyarakat minoritas yang tidak memiliki kekuatan, maka prinsif dakwah adalah diperbolehkannya meninggalkan jihad dan amar ma'ruf dengan kekuatan/kekuasaan dan lisan, akan tetapi semua itu tidak menafikan ingkar dengan hati. Sikap tersebut wajib dilakukan dalam setiap kesempatan, karena tidak adanya fitnah yang ditimbulkan. Syaikhul Islam Ibnu Taimiyah berkata: "Adapun hati wajib mengingkari dalam berbagai keadaan, karena tidak adanya bahaya kala melakukannya. ${ }^{33}$

Syaikh Shalih Fawzan menyatakan bahwaberinteraksi dengan penguasa kafir, maka sikap yang dilakukan berbeda sesuai dengan keadaan, jika mereka memiliki kemampuan, dan kekuatan dalam memerangi dan meruntuhkan kekuasaan mereka, maka hal itu wajib bagi kaummuslimin, bahkan termasuk jihad di jalan Allah, lalu jika mereka tidak memiliki kemampuan untuk hal itu, maka tidak diperbolehkan bagi mereka melakukan perlawanan kepada penguasa, karena sikap yang demikian akan mengakibatkan bahaya bahkan penumpasan terhadap kaum muslimin. ${ }^{34}$

Dalam penjelasan di atas dapat diketahui bahwa kaidah prinsif dakwah Islam di negara yang bukan Islam atau di negara minoritas kaum muslimin, harus disesuaikan dengan kondisi ummat Islam. Penegakan syari'at dan jihad serta amar ma'ruf dan nahi mungkar disesuaikan dengan kemampuan, tidak harus ditegakkan karena kondisi yang kurang menguntungkan bagi keberadaan ummat Islamitu sendiri. Amar ma'ruf nahi mungkar untuk menghilangkan kerusakan (mafsadah) boleh ditinggalkan, kalau menimbulkan mafsadah yang lebih besar. Namun kaum muslimin tetap diwajibkan menjalankan kewajibannya secara

32 Ibnu Taimiyah, Asy-Siyasah Asy-Syar'iyah, hlm. 162

33 Ibnu Taimiyah, Al-Istiqamah, hlm. 212

34 Dikutip dari Fawwaz bin Hulayyil as-Suahaimi, Beginilah Seharusnya Berdakwah, Darul Haq Jakarta, Terjemahan Beni Sarbeni LC. Tahun 2013 hlm. 123 


\section{Kamaluddin}

pribadi serta membenci dengan hati segala kemungkaran yang ada dihadapannya.

\section{Penutup}

Dakwah Islam memiliki kaidah-kaidah yang melahirkan beberapa prinsif. Prinsif-prinsif tersebut sangat penting dipedomani oleh para pelaksana dakwah, baik sebagai lembaga maupun individu, karena dengan penerapannya, dakwah akan dapat berjalan dengan efektip sesuai petunjuk al-Qur'an, al-Hadis dan ijtihad para ulama. Prinsif-prinsif tersebut menyangkut pendakwah, materi pesan dakwah, metode dan lingkungan dakwah. Prinsif strategi dakwah antara lain adalah keharmonisan antara kelembutan dan ketegasan, amar ma'ruf nahi mungkar sesuai kemampuan yang dimiliki agar tidak menimbulkan kerusakan yang lebih besar. Tidak ada paksaan dalam dakwah. Demikian juga dalam aspek sosial- budaya, terdapatprinsif mengambil hal-hal lama yang baik dan menolak hal-hal baru yang tidak baik. Da'i hanya dituntut menerapkan proses sesuai kaidah prinsif-prinsif yang ditetapkan, sedangkan efek tergantung kepada hidayah Allah swt.

\section{Daftar Pustaka}

Ali bin Wahf al Qahthani, Fiqh Ad-Dakwah Fi Shahih Al-Imam Al-Bukhari, Dar al-Fikri Beirut, tt.

A.llyas Ismail, Filsafat Dakwah, Kencana Prenada Media Group, Jakarta 2013

Al-Bukhari, Imam. Shahih Bukhari, Toha Putra Semarang, t.t.

Departemen Agama RI, A/-Qur'an Dan Terjemahnya, CV. Diponegoro, 2005

Fawwaz bin Hulayyil as-Suhaimi, Begini Seharusnya Berdakwah, Terjemahan BeniSarbeni LC. Darul Haq Jakarta, 2013

Ibnu Taimiyah, Asy-Siyasah Asy-Syar'iyah, Dar al-Kutub al-Arabiy, t.t.

Ibnu Taimiyah, Al-Istiqamah, Dar al- Kutub al-Arabiy, t.t.

Jum'ah Amin Abdul Aziz, Fiqih Dakwah, Terjemahan Abdus Salam Masykur, Era Intermedia Solo, Tahun 2000

Muslim Al-Hajjaj, Imam. Shahih Muslim, Beirut Muassasah ar-Risalah, 1970. 
Musthafa Malaikah, Manhaj Dakwah Yusuf Qaradlawi, Terjemahan Samson Rahman, Pustaka al-Kautsar Jakarta tahun 2001

Sayyid Quthub, Figh Al-Da'wah Mawdlu'at fi Al-Da'wah wa Al-Harakat, Beirut, Muassasah ar-Risalah, 1970.

Syukur Kholil, Dampak Teknologi Informasi Terhadap Pribadi Remaja, dalam H. Abdullah, Dakwah Humanis, Citapustaka Media Bandung, 2014. 